\title{
Russian scientists cut off from Springer journals
}

\section{Access lost after last year's institutional subscription fees were not paid.}

\section{Quirin Schiermeier}

21 May 2015

Following a row over unpaid bills, the journal publisher Springer has cancelled institutional subscriptions to its large portfolio of scientific journals for hundreds of Russian universities and research institutes.

Springer (which completed a merger with Nature's publisher this month) and Russia's science minister both say that they are hoping to resolve the problem soon. But the missed payment and subsequent loss of access is one more example of how Russia's weak economic situation is affecting scientists, who are already finding it harder to purchase and import overseas equipment, says Fyodor Kondrashov, a Russian biologist with the Centre for Genomic Regulation in Barcelona, Spain.

The news of Springer's decision to cut off access was first reported by Russian news agencies on 12 May. The Russian Foundation for Basic Research (RFBR), a government-controlled grant-giving organization, failed to pay some $€ 890,000$ (US $\$ 1$ million) it owes Springer for 2014 subscriptions to more than 2,000 publications, according to Matthias Aicher, a sales agent who sells Springer products to universities in Russia and the Commonwealth of Independent States.

Vladimir Fortov, the head of the Russian Academy of Sciences, told the newspaper Kommersant that a lack of access to Englishlanguage foreign journals could undermine the development of Russian science.

Springer and the Russian government are discussing possible solutions, says Eric Merkel-Sobotta, a Berlin-based spokesperson for Springer. "We are confident that a solution will be found promptly so that the Russian research community will have sustained access to Springer content," he says. Education and science minister Dmitry Livanov also pledged last week in Russian media that his country's research institutes' access to Springer publications would be restored in due course.

Russia's weak economic situation is thought to lie behind the RFBR's problems. The falling value of the rouble has thrown many of the country's science organisations into financial disarray, particularly for overseas purchases, although Livanov told Nature in January that economic troubles would not lead to reductions in levels of science funding, which was set at a level of 834 billion roubles per year (then US\$13 billion, now US\$17 billion at current exchange rates).

But Kondrashov also blames government dysfunction for the missed bill. "The inability to foot subscription fees is just another example of the Russian government's unprofessional and utterly inadequate centralized management of science," he says. Russian government officials did not respond to questions from Nature's news team.

Nature | doi:10.1038/nature.2015.17584 